\title{
AN EVALUATION ON THE POLICIES ON PUBLIC HEALTH WORKERS AS HEALTH PROFESSIONALS
}

\author{
* Muswandar, ** Purnawan Junadi \\ * Program Studi Ilmu Kesehatan Masyarakat, Peminatan Kebijakan Hukum dan Kesehatan \\ ** Departemen Administrasi Kebijakan Kesehatan. Fakultas Kesehatan Masyarakat Universitas Indonesia, Kampus Baru \\ UI Depok 16424, Indonesia
}

Email : muswandariwan@gmail.com

\begin{abstract}
Law No. 36 of 2014 is a comprehensive law for health professionals. In that regulation, all health graduates that wish to practice their trade must have a letter of registration (STR). That policy also separated environmental health from public health. This was the reason why we decided to evaluate the policy that is related to public health professionals. This evaluation was a retrospective analysis that used in-depth interviews and literary research, respectively as primary and secondary data. From this research we discovered that public health graduates is has their own profession. And to obtain the right to practice their trade, they must pass the competence standard test. However, according to other regulations, only vocational or professional education graduates can participate in the test. Since there currently are no professional education institutions available for public health professionals, Minister of Health Regulation No. 41/2013 takes over. According to this law, all public health graduates will be provided an STR until there is a professional education institution. We also discovered that environmental health should NOT be separated from public health, since it is a large part of it. And therefore, the law must be amended.
\end{abstract}

Keywords: Policy evaluation, Content analysis, public health professional competence test.

Abstrak. Undang-undang (UU) No. 36 Tahun 2014 mengatur tenaga kesehatan secara komprehensif. Dalam UU tersebut, semua tenaga kesehatan yang berpraktek wajib memiliki surat tanda registrasi (STR). Kebijakan juga telah memisahkan kesehatan lingkungan dari kesehatan masyarakat (kesmas). Oleh karena itu peneliti tertarik untuk melakukan evaluasi kebijakan khususnya terhadap konten kebijakan yang berhubungan dengan tenaga kesmas. Evaluasi isi kebijakan ini dilakukan dengan analisis retrospektif yang menggunakan wawancara mendalam dan telaah literatur sebagai data primer dan sekunder. Dari penelitian ini diketahui bahwa tenaga kesehatan masyarakat layak disebut sebagai sebuah profesi. Untuk mendapatkan STR, tenaga kesmas harus lulus ujian kompetensi. Tetapi, menurut peraturan yang berlaku, yang dapat mengikuti ujian kompetensi adalah lulusan pendidikan vokasi atau profesi. Namun, karena belum adanya pendidikan profesi untuk tenaga kesmas, maka untuk sementara Peraturan Menteri Kesehatan Nomor 41 Tahun 2013 digunakan sebagai solusi. Dimana semua lulusan institusi kesmas akan mendapatkan STR hingga terdapat institusi pendidikan yang menyelenggarakan pendidikan profesi. Selain itu ditemukan bahwa kesling sebenarnya merupakan bagian yang penting dari kesmas, baik dalam literatur maupun pendapat para ahli. Sehingga sebaiknya dilakukan revisi atau amandemen untuk UU tersebut.

Kata kunci: Evaluasi kebijakan, Analisis isi, Uji kompentensi SKM.

\section{INTRODUCTION}

There are many laws and regulations on health professionals, but a specific law was not available until law no. 36 on Health Workers was issued in 2014. This law also regulated the general tasks and qualifications of public health workers. According to this law, public health workers included health epidemiologists, health promotion and behavioural experts, occupational health counselors, health administration and policy experts, biostatistics and population experts, also reproductive and family health experts. ${ }^{1}$

It also stipulated that all health workers that wished to practice their trade mustb e registered to the government. And to obtain this, they must prove their competence by passing the national competence test. However, those whom are eligible to participate in this test, according to the regulations, are graduates from vocational or professional schools. Unfortunately, although public health professionals are, indeed, health workers, they do not have a vocational or professional education institution. Therefore, public health workers 
are not eligible for obtaining a letter of registration (STR). This is a problem, because there are currently many public health graduates (SKM) that are not registered, but have provided health services. Law no. 36/2014 also separated environmental health from the realm of public health. ${ }^{1}$ Even when no expert or literature has separated it.

For the reasons above, we were interested in evaluating the policies within that law, particularly on the policies related to public health workers. Policy evaluation is the last part of the implementation of a policy, which is done because not all policies will reach their goals. When this happens, the policy is evaluated to discover the causes of the failure and whether or not it has been implemented correctly. ${ }^{2}$

\section{METHOD}

To discover whether the activities done by the public health workers comply with law no. 36/2014, this research used the qualitative approach that evaluates the contents of the policy through retrospective analysis. The data used was primary data from in-depth interviews and secondary data from documents.

\section{RESULT AND DISCUSSION}

\section{Public Health Workers as Professionals}

Public health workers are people that devoted themselves to public health and has the knowledge and skills to do so. According to Law no. 36/2014, it is one type of health profession. ${ }^{1}$ However, there is no professional educational institute that handles it.

According to Bell, a profession is a studied intellectual activity which includes formal and informal training and also possesses a certificate issued by a a group/ organization that is accountable for that field when serving the community, and has its own professional ethics and morals in applying their competences and technical skills. ${ }^{3}$ While the Indonesian Language Great Dictionary, profession is a field of work that is based on education in a certain expertise (skills, vocational, etc.). ${ }^{4}$ Which means that vocational education alone cannot make it a profession. In addition to theory, skills mastery is also required, to connect theory with practice. ${ }^{5}$ Therefore, public health education in Indonesia must change, the institutions of higher educatons must complement academic education with professional training.

From the in-depth interviews, we discovered that the respondents has understood that public health workers is a health professional just as doctors and nurses are. Which is evident in the following quotation:
"This law is the role of IAKMI, for the public health professional and the general health profession. At first public health workers were not included in health profession, it was another profession group that coincidentally worked in the health field. As a profession, public health workers have different scientific base, its institution is separate, and its position in the university is clear. Whom are the clients? It could be a community, the government, or the private sector. If midwife diploma holders are acknowledged as a profession, Bachelors should also be. The premise is: 1) Health is a necessity, 2) When one understands health, he will demand health, 3) The health system, 4) The oldest university that studies the health system has a public health faculty."

From the opinion above, we derived that public health schools is more than just an academical institution, it is also a vocational school. Which has studies the health system fom the beginning, therefore no vocational education is necessary. Accoding to De George, a profession is a job that is done to earn a living wage that relies on a certain skill, with the following characteristics: ${ }^{5}$

1) Have a certain proficiency, which comprises of skills and expertise that is gained theough many years of study, training, and experience.

2) Have norms and high moral standards, or a professional code of ethics.

3) Serving the community, which means that the professional must place the community's needs before their own.

4) Have a certain permit to practice that rofession. Each profession involving public interests must have a permit that guarantees the safety, security, survival, etc of the public.

\section{Competence Test}

Health endeavors must be performed by responsible health workers with high ethical and moral standards, skills and knowledge that is continuously renewed through continuing education, certification, registration, permits, guidance, monitoring, and surveillance to maintain the quality of healthcare. To obtain that registration, certification, and permit, public health graduates are required to participate in the national competence test. The problem is that the testing itself does not comply with law no. 36/2014.

In that law, those that can participate in a competence test are vocational or professional students. Article 21 verse 1 Law no. 36/2014 stated that health students at 
the endo $f$ their vocational and professional training must participate in a national competence test. ${ }^{1}$ However, several informants were still doubtful in this test, because public health does not have a vocational or professional school. Which is evident in the following quotation:

"The competence test was done because the large numbero $f$ midwives that weren're ready that were pushed into he field and given SIPs. I don't really know if public health workers needs SIPs. If public health educational institutions don't have a professional education, they they should follw the law." (Informant 2)

While some agreed to the competence testing for public health workers. Which is evident in the following quote:

\begin{abstract}
"Why do we have to perform a competence test? The quality of the education in our field is highly diverse in each region. Pardon me, for instance java and east nusa tenggara graduates. The worst test grade from graduates from UI would have higher marks then other schools. For example, even with so many midwives, the MMR is still high. Ofcouse they're not competent, they only got 4 point some thing when they graduated, this also happened to public health bachelors. Private universities rejected the competence test, and when they were tested, many really didn't pass the test. So we should also take into consideration what happens in the field, not just the regulations. Right now public health doesn't have permission from the Dikti, but we pushed through, the MTKI admitted it." (Informant 1)
\end{abstract}

The competence test is regulated by Law no. 12/2012 on higher education, ${ }^{6}$ Ministry of Education and Culture Regulation No. 83/2013 on Certificate of Competence, ${ }^{7}$ Ministry of Health and Ministry of Education and Culture Cooperative Regulation No. $36 / 2013^{8}$ and No. $1 / \mathrm{IV} / \mathrm{PB} / 2013^{9}$ on Competence Testing for University Students in the Health Field, and Ministry of Health Regulation No. 41/2013 stated that the competence test is a process to measure the knowledge, skills, and attitude of health workers according to the professional standards. By requiring health professionals working at healthcare facilities to have an STR, automatically, they are obligated to pass the competence test. ${ }^{10}$

This test also acts as a selection method for health institution gaduates. Although health educational institutions are a dime a dozen in our country, the quality of each institution might differ. This was also because many think that health institute graduates can find work easier and can easily become civil servants. As a result, some miscreants would abuse this phenomenon and establish health schools disregarding the quality of the education and its graduates. The quality of the graduates can be guaranteed with a competence test. Because the test is a national test, the materials and questions are the same at any region. The questions were created by the central Indonesian Health Workers Assembly (MTKI) in Jakarta and is distributed to the Provincial Health Workers Assembly (MTKP) at the regions, in confidentiality. This was also stated by the experts in the following quote:

"The law states that the

others are banned, if there aren't any, can we? Why a competence test, because suddenly we have 160 institutions with different curiculums. Public health bachelors from UI would differ with public health bachelors from Papua. This shouldn't be allowed. That's why we standardized it with a competence test, so that our students will have the skills."

The materials tested was also regulated in article 166 , verse 2, law no. 36/2014, where it stated that the professional standards and healthcare standards are set by the professional organization and approved by the Ministry of Health. This meant that the materials for the competence test was set by each professional organization. Which is why the professional standards sent by IAKMI and PERSAKMI was not processed by the Ministry of Health.

The Ministry of Research, Technology, and Higher Education also has sent a letter to both professional organizations through the Directorate General of Learning and Student Isues (Belmawa) in letter no. $311 / \mathrm{B} / \mathrm{TU} / 2018$ on the implementation of the competence test, which included:

1) A statement from the Dirgen Belmawa that supported the competence test, as long as it was within the professional realm, and not a requirement for graduation.

2) Dirgen Belmawa emphasized that the UKSKMI that is now in force cannot use law no. 12/2012 on Higher Education, law No. 36/2014 on Health Workers and Permenristekdikti No. 12/2016 on the Procedures of the Competence Testing for Students in the Health Field as a base. Because it is clearly written that only students at the endo f their vocational and professional training can participate in the competence test.

3) Dirgen Belmawa also requested that the public health professional community (IAKMI, 
AIPTKMI, and Persakmi) to come to an agreement on the concept for the professional education, and that it should comply with the national programs of the Ministry of Health.

Based on that letter, the competence test for public health bachelors are illegal until the public health educational institution has its own vocational or professional training or education facility.

\section{Solution for the STR for Public Health Workers}

Permenkes RI no. 41/2013 on Health Worker Regsitration stated that STRs can only be provided to health workers that have a diploma from their institution and has passed the competence test. The competence certificate is a letter that guarantees the competence of a hwalth worker in performing their profession or practices. $^{9}$

From in-depth interviews we discovered that all the informants agree that public health workers must be registered. But some still insist that there should be a profession training for public health graduates, so they recommend the establishment of such an institution. However, this would take some time. In the mean time, ow shall we solve the STR problem?.

We discovered that in Permenkes no. 41/2013 there is a stipulation that may help. Article 30 of said regulation stated that health workers that have in their posesion an STR/licence to practice before this regulation was enforced, will be considered to have an STR until the STR is expired. While working or newly graduated public health workers will still be provided an STR until their institution establishes a professional training facility. ${ }^{9}$

\section{Environmental Health is Not a Part of Public Health}

Law no. 36/2014 separated environmental health from public health. According to that law, environmental health is a separate group of health worker. ${ }^{1}$ Although the previous law (Law no. 36/2009) stated that it is a part of public health. ${ }^{11}$ Most informants disagree with this separation and none understood why it was separated.

According to public health theories, environmental health is an important indivisible part of public health. Basically, public health is a science and art with goals that prevents diseases, prolong life, and improve health quality of health through public organizing to improve environmental sanitation, eradication of communicable diseases, and health education. ${ }^{12}$ According to Hendrick L. Blumm, there are 4 factors that influence it, they are the behavior, the environment, the inherited, and the healthcare service factors. All four factors intertwine and influence each other. However, behavior has the largest impact, followed by the environment, healthcare services, and inherited factors. ${ }^{13}$ Experts also did not agree in the separation, as evident in the quote below:

"Because of HAKLI that
feels that they aren't a part of public
health, although I have shown them the
theores on the contributions of
environment to health. So its strange if
you don't think environmental health as
a part of public health. So in the future,
it will be united, IAKMI will act as the
premier authority, with HAKLI, K3, the
colegiums or specialists under it. So
don't look at what's there now, you
should see the future."

Fundamentally, public health is a science that comprises of various other subjects, such as biology, physics, chemistry, medicine, environment, sociology, psychology, anthropology, economy, administration, education, etc. however, there are 8 hallmarks of public health, they are: ${ }^{13}$

1) Public Health Administration.

2) Health Education and Behavioral Sciences.

3) Biostatistics/Health Statistics.

4) Environmental Health.

5) Community Nutrition.

6) Occupational Health.

7) Epidemiology.

8) Reproduction Health.

Therefore, we can summarize that environmental health is an indivisible part of public health. And is even the largest part of it. ${ }^{12,13}$

\section{CONCLUSION}

Based on Law no. 36/2014 on health workers, public health workers is one of the professions in the health field. And to obtain the right to practice their trade, they must have an STR. Which will only provided to graduates that have passed the national competence test. However, according to other regulations, only vocational or professional education graduates can participate in the test. The Ministry of Research, Technology and Higher Education did not outrule this test as long as the competence test is not an exit exam. And since there currently are no professional education institutions available for public health workers, the Minister of Health Regulation No. 41/2013 takes over. According to this law, all public health graduates will be provided an STR until there is a professional education institution. We also discovered that environmental health should NOT be separated from public health, since it is a large part of it. And therefore, the law must be amended. 


\section{REFERENCES}

Undang-Undang Republik Indonesia Nomor 36 Tahun 2014 tentang Tenaga Kesehatan. Jakarta, 2014.

Winarno B. Kebijakan Publik: Teori, Proses, dan Studi Kasus. CAPS. Yogyakarta, 2012.

Bell D. The Coming of Industrial Society. Basic Books. New York, 1973.

Ebta Setiawan. Kamus Besar Bahasa Indonesia versi daring. Diunduh dari https://kbbi.web.id/profesi pada tanggal 27 Oktober 2018.

Nawawi I. Public Policy: Analisis, Strategi Advokasi Teori dan Praktek. PMN \& ITS Press. Surabaya, 2009.

Undang-Undang Republik Indonesia Nomor 12 Tahun 2012 tentang Pendidikan Tinggi. Jakarta, 2012.

Peraturan Menteri Pendidikan dan Kebudayaan No. 83/2013 tentang Sertifikat Kompetensi. Jakarta, 2013.

Peraturan Bersama Menteri Kesehatan dan Menteri Pendidikan dan Kebudayaan No. 36/2013 tentang Uji Kompetensi bagi Mahasiwa Perguruan Tinggi Bidang Kesehatan. Jakarta, 2013.

Peraturan Bersama Menteri Kesehatan dan Menteri Pendidikan dan Kebudayaan No. 1/IV/PB/2013 tentang Uji Kompetensi bagi Mahasiwa Perguruan Tinggi Bidang Kesehatan. Jakarta, 2013.

Peraturan Menteri Kesehatan Nomor 41 Tahun 2013 Tentang Registrasi Tenaga Kesehatan. Jakarta, 2013.

Surat Direktorat Jenderal Pembelajaran dan Kemahasiswaan Kemenristek Dikti (Bamelwa) no. 311/B/TU/2018. Jakarta, 2018.

Undang-Undang Republik Indonesia Nomor 36 Tahun 2009 tentang Kesehatan. Jakarta, 2009.

Notoatmojo S. Kesehatan Masyarakat Ilmu dan Seni. PT. Rineka Cipta. Jakarta, 2003.

Notoatmojo S. Ilmu Kesehatan Masyarakat. PT. Rineka Cipta. Jakarta, 2007. 